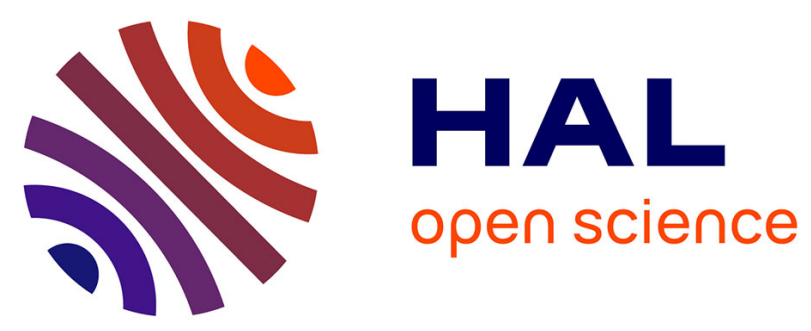

\title{
Analysis of Inter-firm Co-operation in Joint Research and Development Projects
}

Matti Majuri, Hasse Nylund, Minna Lanz

\section{To cite this version:}

Matti Majuri, Hasse Nylund, Minna Lanz. Analysis of Inter-firm Co-operation in Joint Research and Development Projects. IFIP International Conference on Advances in Production Management Systems (APMS), Sep 2016, Iguassu Falls, Brazil. pp.536-543, 10.1007/978-3-319-51133-7_64 . hal01615798

\section{HAL Id: hal-01615798 \\ https://hal.inria.fr/hal-01615798}

Submitted on 12 Oct 2017

HAL is a multi-disciplinary open access archive for the deposit and dissemination of scientific research documents, whether they are published or not. The documents may come from teaching and research institutions in France or abroad, or from public or private research centers.
L'archive ouverte pluridisciplinaire HAL, est destinée au dépôt et à la diffusion de documents scientifiques de niveau recherche, publiés ou non, émanant des établissements d'enseignement et de recherche français ou étrangers, des laboratoires publics ou privés. 


\title{
Analysis of Inter-firm Co-operation in Joint Research and Development Projects
}

\author{
Matti Majuri*, Hasse Nylund and Minna Lanz \\ Tampere University of Technology, Tampere, Finland \\ \{matti.majuri, hasse.nylund, minna.lanz\}@tut.fi
}

\begin{abstract}
Companies need to renew themselves to be able to compete in the dynamic global markets. Especially for the SMEs this is often challenging due to their weaker risk tolerance and fewer resources. Co-operation is often considered to be effective way to tackle these challenges and considerable amount of public funding has been directed to stimulate this co-operation. Still, deep research and development $(\mathrm{R} \& \mathrm{D})$ co-operation between companies exists rarely. The paper presents qualitative analysis on co-operation in two joint $R \& D$ projects. The level of inter-firm co-creation in studied cases was low. This was explained by lack of resources, differences of R\&D goals and changes in project consortium. Finally, we present two possible solutions to increase the level of inter-firm co-creation in joint $R \& D$ projects.
\end{abstract}

Keywords: Networks $\cdot$ Renewal $\cdot$ Innovation $\cdot R \& D$

\section{Introduction}

Rapid changing markets and increasing competition have led to a situation where ability for renewal has become one of the dominant capabilities in the pursuit of competitive advantage [1]. The renewal may focus on processes, offering or business concepts and can be radical or incremental by nature. Challenges related to renewal are somewhat different between large companies and SMEs. SMEs have typically less bureaucracy and more concentrated ownership, which in general support agility. Additionally, with fewer resources, the personnel of SMEs' are used to work in wider scope of processes, which in turn supports flexibility. On the other hand, compared to the large companies, SMEs' have typically weaker risk tolerance, smaller knowledge base, fewer sales channels and narrower offering. All of these factors can be considered essential for successful renewal, development and innovation. Inter-firm co-operation creates a major opportunity to tackle these challenges and altogether enables firms to achieve stronger position than they could alone [2].

In general, deep inter-firm R\&D co-operation between SMEs in the Finnish technology industry is rare [3]. On the other hand, several public funding instruments require this co-operation and multiple organizations have been established to support the cooperation. Focus of the paper is on collaborative $R \& D$ projects that received funding

adfa, p. 1, 2011.

(C) Springer-Verlag Berlin Heidelberg 2011 
from Tekes, Finnish Funding Agency for Innovation. The paper increases understanding on the challenges and opportunities the companies are facing in their co-operation attempts during these projects. Research data was collected with eight semi-structured company interviews in two separate $\mathrm{R} \& \mathrm{D}$ projects.

\section{Joint Research and Development Projects}

The research concerning inter-firm R\&D co-operation is fragmented. Several frameworks and concepts from multiple fields of science have been presented to model the dynamics of inter-firm co-operation. Majority of the studies concerning inter-firm cooperation seem to be quantitative by their nature, although this was not systematically studied. In recent years concept of open innovation has got a lot of attention. Open innovation processes includes outbound, inbound and coupled processes [4] from which coupled processes are closest to the topic of this study. However, the research focusing on coupled processes does not seem to include inter-firm joint R\&D projects in which the companies are from different value chains.

Hagerdoorn [5] has created classification for co-operative agreements based on the amount of the organizational interdependence, which can be considered to be a central dimension defining the mode of co-operation. The classification has four main modes: (1) Joint R\&D ventures, (2) Joint R\&D and technology exchange agreements, (3) Equity investments and (4) Customer-supplier relationships and one-directional technology flows. The second mode is divided into three categories: joint research pacts, joint development agreements and technology sharing agreements. Study presented in this paper contributes to the areas of joint research pacts and joint development agreements.

Barnes et. al. [6] have identified 40 success factors for inter-firm co-operation which they have divided into six categories: choice of partner, project management, universal success factors, ensuring equality, monitoring environmental influences, project manager and choice of partner. Lee et. al. [7] have summarized intermediary's role in SME innovation networks based on literature review into framework that consists of five. Categories: Network Database, Network Construction, Network Management, Culture of co-operation and Facilitation of co-operation. Frameworks that illustrate the characteristics and dynamics of R\&D inter-firm network are presented by e.g. Kirkels [8], Esterhuizen et. al. [9], Möller et. al. [10], and Dasgupta and Gupta [11].

The frameworks have plenty of similarities but they are still different. A conclusion can be made, that the inter-firm co-operation as a phenomenon is heavily case dependent. None of studies dealt with the same situation as ours. Therefore it is justified to increase the understanding on inter-firm $R \& D$ co-operation from perspective of this paper. At least the following features can be considered to be defining in our study: public funding, significant role of research institute, project-centeredness, formality, non-equity, non-value chain and technological orientation of R\&D topics. Considering the high volume of joint $R \& D$ projects receiving public support they are surprisingly rarely in the focus of the qualitative studies, which could provide in depth knowledge on the phenomenon. 


\section{Method}

Priority of our research was to deepen the understanding on actual experiences that companies had on inter-firm co-operation in publically funded join R\&D projects. Research approach was qualitative and inductive. This approach was chosen due to fragmentation of the previous research and case dependence of the phenomenon dynamics.

The data was collected by interviewing eight persons from eight companies that had been participants in collaborative R\&D projects funded by Tekes. Interviews were semi-structured and they lasted 75 minutes on average. Central answers concerning project phases, quantity and quality of co-operation, goal achievement and co-operation characteristics were collected into an excel sheet that was visible for the interviewee during the interview. The interviewees were asked to define the project phases freely according to project goals they found relevant. Illustration of the excel sheet is presented on Table 1. There was also data collected concerning the co-operation with research institutes, but it is not in the focus of this paper.

All interviewees were the major participants in the projects from their companies. Introduction for the interviewee about research objectives was kept short to avoid inducement. All interviews were recorded and transcribed. Atlas TI computer program was used for qualitative coding.

Table 1. Excel sheet base filled with the interviewee

\begin{tabular}{|l|l|l|l|}
\hline Number of the project phase & 1 & $\ldots$ & $\mathrm{n}$ \\
\hline Goal of the project phase & & & \\
\hline $\begin{array}{l}\text { The amount of the collaboration with research institutes } \\
0=\text { none, } 1=\text { little, } 2=\text { moderately, } 3=\text { plenty }\end{array}$ & & \\
\hline $\begin{array}{l}\text { The quality of the collaboration with research institutes } \\
0=\text { poor, } 1=\text { moderate } 2=\text { high }\end{array}$ & & & \\
\hline $\begin{array}{l}\text { The amount of the collaboration with other companies in the } \\
\text { project }\end{array}$ & & & \\
\hline $\begin{array}{l}\text { The quality of the collaboration with other companies in the } \\
\text { project }\end{array}$ & & & \\
\hline $\begin{array}{l}\text { Goal achievement } \\
0=\text { not achieved, } 1=\text { achieved partially, 2= achieved well }\end{array}$ & & & \\
\hline
\end{tabular}

Aim of the paper is to answer the following research questions:

1. What characteristics companies associate with high and low quality inter-firm cooperation?

2. What reasons explain the realized amount of co-operation?

Additionally, the paper gives suggestions for new project structures that would increase the quality and quantity of inter-firm co-operation in $R \& D$ projects. There is also data presented on the amount of co-operation between companies and also between compa- 
nies and research institutes. However, this data cannot be generalized due to small sample size, but it can be considered to be useful for planning future research and also to stimulate the public discussion on the matter.

The research presented in this paper is part of the ongoing research project called Renaissance of the Regions (ReRe) - Challenging the Status Quo of Innovation Policy Implementation in Regional Manufacturing Networks. Project goal is to create improved methods and means for public or private network coordinators to support and develop the innovation process in SME networks. To be able to work efficiently it is necessary that the coordinator has an understanding on what characteristics high quality co-operation consists of. Understanding on the mechanisms how to influence those characteristics and on the mechanisms how those characteristics influence the co-operation is also needed. Additionally, this understanding is valuable also for the companies. With deeper understanding they are able to manage their co-operation activities and capabilities more coherently to support their innovation co-operation with other companies.

Tampere University of Technology's research goal in the ReRe project is to create generic model for evaluating the status of prioritized co-operation characteristics in DIR network (Development, Innovation, Renewal). Table 2 explains the research phases. The results and analysis presented in this paper contributes to the current state analysis. They also create valuable information for planning a web survey on phase 2 .

Table 2. Research phases.

\begin{tabular}{|l|l|l|}
\hline Phase No. & Phase & Methodology \\
\hline 1. & Current state analysis & Literature review and qualitative study (interviews) \\
\hline 2. & Generalization & Quantitative study (web survey) \\
\hline 3. & Deepening the understanding & Qualitative study (intreviews) \\
\hline 4. & Synthesis & $\begin{array}{l}\text { Combining and evaluation of the knowledge from } \\
\text { phases 1 to 3 (expert workshops) }\end{array}$ \\
\hline 5. & Verification & $\begin{array}{l}\text { Testing the model by using it to analyze 3 to 5 DIR } \\
\text { networks }\end{array}$ \\
\hline
\end{tabular}

\section{$4 \quad$ Interview Outcomes}

Table 3 presents the amount of co-operation the interviewed company had with other companies and with the research institutes during the different phases of the project. It also presents the quality of the co-operation in each phase and how well the goals were achieved. 
Table 3. Amount and quality of cooperation.

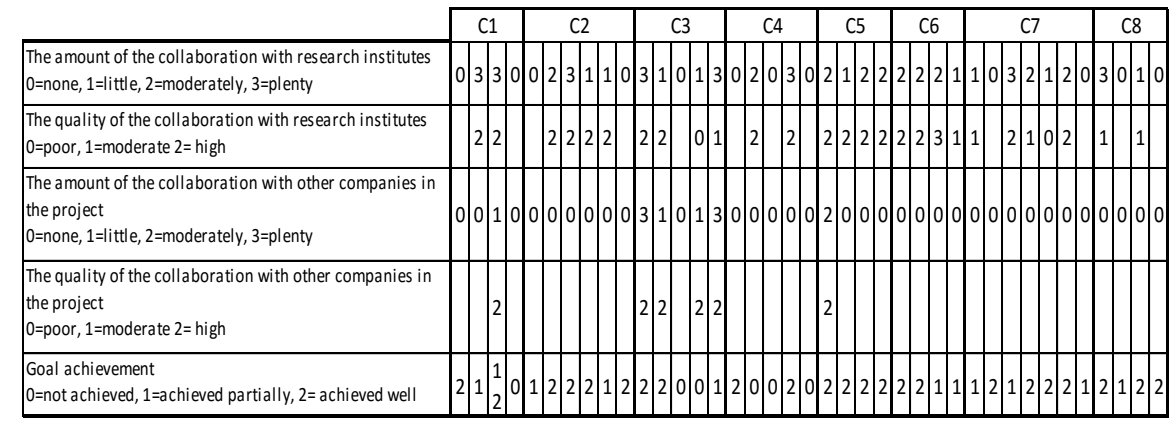

Although the study sample is small and as such not generalizable, it was still surprising to notify how little inter-firm co-operation existed. With further analysis on the transcribed interviews we formed Table 4, which includes explanations the companies gave for the low amount of inter-firm co-operation.

Table 4. Explanations for the lack of inter-firm co-operation.

\begin{tabular}{|c|c|}
\hline $\mathrm{C} 1$ & $\begin{array}{l}\text { Company with synergetic business interests left the project in early stage. This was possibly due to financial } \\
\text { challenges. }\end{array}$ \\
\hline & Other companies were distant. \\
\hline $\mathrm{C2}$ & Other companies had different focusses in their R\&D. \\
\hline & Company, that was considered as a potential partner, focused on different technology. \\
\hline C3 & $\begin{array}{l}\text { Big customer, that encouraged C3 to participate, did not participate the "group project". The customer was not able } \\
\text { to reach an agreement with other participating companies. }\end{array}$ \\
\hline & Other companies were already in their own networks, and P3 was not able to fit into them. \\
\hline C4 & $\begin{array}{l}\text { Other companies were interested in C4 part, but did not want to allocate resources to collaboration. From business } \\
\text { perspective the times were difficult and this affected the resourcing. }\end{array}$ \\
\hline & One potentian company to do collaboration with left out just before project started \\
\hline C5 & $\begin{array}{l}\text { Project topic in } \mathrm{C} 5 \text { was different. Other companies focused on product development when C5's aim was to develope } \\
\text { ther risk management processes. }\end{array}$ \\
\hline & Insufficient resources in C5. \\
\hline C6 & R\&D subjects were close, but not close enough to do collaborative development \\
\hline C7 & Lack of resourcing in C7. Collaboration would have required human resources from wide range of functions in C7) \\
\hline & Scope of R\&D was such that it did not lead to collaboration. \\
\hline $\mathrm{C8}$ & $\begin{array}{l}\text { Desired results were delivered with very little collaboration. Knowledge exchange between companies happened } \\
\text { through research organization. }\end{array}$ \\
\hline
\end{tabular}

Due to small amount of inter-firm co-operation it was natural that the data did not offer much information on the co-operation characteristics. Since all inter-firm co-operation was considered by the interviewees' to be of high-quality (Table 2.) only characteristics describing high-quality can be listed. Characteristics describing high-quality 
inter-firm co-operation are: (i) Common vision; (ii) Partner was showing trust; (iii) Encouragement by the partner; (iv) Desire to help; (v) Honest and straight dialogue; (vi) Good relations; (vii) Openness Experienced appreciation; (viii) Similar commercial goals.

\section{Conclusions and Discussion}

In this paper the characteristics of inter-firm R\&D co-operation in the Finnish technology industry was discussed. The explanations for the lack of inter-firm co-operation in a joint research project, presented in Table 4, can be summarized with the following three categories:

1. Own R\&D goal was different from the ones other companies had

2. The project consortium changed into less synergetic

3. Qualitative of quantitative lack of resources

The projects that we studied were put together mainly by research institutes which had their own research projects going alongside the companies' $\mathrm{R} \& \mathrm{D}$ projects. The construction phase of the projects, including putting the consortium together, is usually carried out fast. This means, that not much resources are allocated into finding companies with similar or synergetic R\&D goals.

Sherer [12] divides the critical success factors for manufacturing networks into trust, commitment, selection choice, information technology, and intermediary. The role of an intermediary, which in our study was a research institute, is important at the construction phase of a project. An intermediary can facilitate networking both by selecting potential participants and aiding companies interested in participating in a R\&D project. Barriers, such as conflicting goals and expectations can be eliminated by an efficient facilitation [13].

One challenge in the forming of the $R \& D$ project is, in addition to the putting the consortium together is a short time, is the small amount of potential companies that can be contacted. Research institutes typically rely on their existing contacts, which narrows down the selection choice of companies. Thorgren et al. [14] state that larger number of companies relates to a greater innovation. The greater number of companies increases the selection choice, which can lead to more synergetic R\&D projects. In the forming phase, trust and commitment is mainly focused on the intermediate in that the potential companies are confident with the intermediate and are more willing to participate in a R\&D project. Potential companies should have clear vision of the R\&D project to invest into it [15].

Trust and commitment is essential in both forming and during a R\&D project. During a $R \& D$ project the role of an intermediate changes more on supporting the participating companies in the trust and commitment issues between the participating companies [16]. The trust and commitment issues between the participating companies emphasizes during a R\&D project. A company should have clear image of the benefits it can gain from the project. In the inter-firm co-operation an important issue is how the co-operation with other companies enhances their own objectives [17]. This requires 
open sharing of information and resources in that opportunities are clear, which is an evident benefit of a functional network [18].

The lack of resources can be explained with both lack of needed skills and lack of time dedicated to the project even when personnel with required skills exist. This can be explained with the short time of construction of a project. It is important that the participating companies are devoted to the ongoing R\&D project. In addition to the role of the intermediate, top management of the companies should recognize the importance of the co-operation [19]. Two relatively different solutions can be identified to tackle these challenges.

The first solution we propose is that there should be knowledge available on the $R \& D$ goals of large amount of companies for the person who is coordinating the project planning, e.g. in some kind of database solution. This would allow contacting widely potential participants that have similar or synergic R\&D interests. When companies with similar genuine $R \& D$ needs would be identified in early stages of the project planning, commitment inside the consortium would rise and fewer changes in the consortium would occur. It should also be noted, that in the studied cases the company participants did not interact together in planning phase and the first face to face meetings were organized after the projects had already started. It is quite likely, that the presented solution would also increase pre-project co-operation, besides increased co-operation during the projects.

In projects with public funding involved, the companies tend to define their R\&D goals with narrow scopes and have often very little resources allocated into free innovative renewal. This is partly because the public funding system requires coherent narrowly defined plans and partly because of small R\&D resources due to hard competition situation in many business fields.

The second solution we suggest would be a kind of hybrid model for the project plan. There would still be straightforward plans with narrow scopes but the project plan would also include resources for loosely defined collaborative R\&D and interaction, e.g. topical workshops. This would create opportunities and space for new ideas that were not possible to be identified in the planning phase of the project. In the current model the project participants become sort of prisoners of the project plan. This leads often to minimal or zero slack and weak co-operation. This is problematic, because slack and co-operation can be considered to be cornerstones of innovativeness [20].

\section{Acknowledgements}

The research presented in this paper is co-financed by Tekes, the Finnish Funding Agency for Technology and Innovation, and Tredea Oy, the Tampere Region Economic Development Agency.

\section{References}

1. Jovane, F.: The Manufuture Road towards Competitive and Sustainable HAV Manufacturing, Tampere Manufacturing Summit, Tampere, Finland (2009) 
2. Boddy, D., Macbeth, D., Wagner, B.: Implementing Co-Operation between Organizations: An Empirical Study of Supply Chain Partnering. Journal of Management Studies, 37(7) (2000)

3. Parhaat, T.: Valmistavan teknologiateollisuuden tutkimusagenda 2020 (in Finnish), Edita Prima Oy, Helsinki, (2011)

4. Enkel, E., Gassman, O. and Chesbrough H.: Open R\&D and Open Innovation: Exploring The Phenomenon. R\&D Management, 39(4), 311-316 (2009)

5. Hagedoorn, J.: Organizational Modes of Inter-Firm Co-Operation and Technology Transfer. Technocation, 10(1), pp. 17-301990

6. Barnes, T.A., Pashby, I.R., Gibbons, A.M.: Managing Collaborative R\&D Projects Development of a Practical Management Tool. International Journal of Project Management 24, 395-404 (2006)

7. Lee, S., Park, G., Yoon, B., Jinwoo, P.: Open Innovation in SMEs - An Intermediated Network Model. Research Policy 39, 290-300 (2010)

8. Kirkels, Y.: Brokerage in SME Networks. Eindhoven University Press, Eindhoven (2010)

9. Esterhuizen, D., Schutte C., du Toit A.: Knowledge Creation Processes as Critical Enablers for Innovation. International Journal of Information Management 32, 354-364 (2012)

10. Möller, K., Rajala, A., Svahn, S.: Strategic Business Nets - Their Type and Management. Journal of Business Research 58, 1274-1284 (2005)

11. Dasgupta, M., Gupta, R.: Innovation Organizations: A Review of the Role of Organizational Learning and Knowledge Management. Global Business Review 10(2), 203-224(2009)

12. Sherer, S.: Critical success factors for manufacturing networks as perceived by network coordinators. Journal of Small Business Management 41 (4), 325-345 (2003)

13. Halme, M., Fadeeva, Z.: Small and Medium-Sized Tourism Enterprises in Sustainable Development Networks. Greener Management International 30, 97-113 (2001)

14. Thorgren, S., Wincent, J., Örtqvist, D.: Designing Interorganizational Networks for Innovation: An Empirical Examination of Network Configuration, Formation and Governance. Journal of Engineering and Technology Management 26 (3), 148-166 (2009)

15. Ahlström-Söderling, R.: SME Strategic Business Networks seen as Learning Organizations. Journal of Small Business and Enterprise Development 10 (4), 444-454 (2003)

16. Hanna, V., Walsh, K.: Small Firm Networks: A Successful Approach to Innovation? R\&D Management 32 (3), 201-207 (2002)

17. Wincent, J.: An Exchange Approach on Firm Cooperative Orientation and Outcomes of Strategic Multilateral Network Participants. Group \& Organization Management 33 (3), 303-329 (2008)

18. Fuller-Love, N., Thomas, E.: Networks in Small Manufacturing Firms. Journal of Small Business and Enterprise Development 11 (2), 244-253 (2004)

19. Huggins, R.: The Success and Failure of Policy-Implemented Inter-Firm Network Initiatives: Motivations, Processes and Structure. Entrepreneurship \& Regional Development 12, $111-135$ (2000)

20. Facó, J. F. B., Csillag, J. M.: Innovativeness of Industry Considering Organizational Slack and Co-operation 109 Journal of Operations and Supply Chain Management 3 (2), 108 120 (2010). 